Сара Мандић*

Филолошки факултет

Универзитет у Београду

Докторанткиња
371.3::811.134.2'243

https://doi.org/10.18485/zivjez.2020.40.1.5

Оригинални научни рад

\title{
СЛАТКА СТРАНА ФРАЗЕОЛОГИЈЕ: АНАЛИЗА ФРАЗЕОЛОГИЗАМА У АЛБАНСКОМ, ГРЧКОМ И СРПСКОМ ЈЕЗИКУ 1
}

Предмет истраживања нашег рада представљају фразеолошке јединице трију несродна балканска језика, албанског, грчког и српског, које у свом саставу садрже неку од кључних лексема за именовање какве слатке намирнице или десерта, коју називамо „слатком компонентом“. Њих и њихове преводне еквиваленте анализирамо путем контрастивно-компаративне методе на семантичком плану са циљем утврђивања сличности и разлика са традиционалним схватањем слатког укуса као нечег веома пријатног и укусног. На основу спроведене анализе, утврђено је да фразеолошке јединице конфигурирају подједнако у позитивним семантичким пољима, као и у негативном семантичком пољу. Како резултати показују, испољавају се разлике по питању њихове мотивације, где сладак укус веома утиче на изразе са позитивном конотацијом, док код фраза са негативном конотацијом не игра значајну улогу.

Кључне речи: балканска фразеологија, фразеологизми, албански језик, грчки језик, српски језик, слаткиши.

\section{1. Циљ и методологија рада}

Истраживање и контрастивно-компаративна анализа фразеолошких јединица често је мултидисциплинарног

* ritasa1905@gmail.com

1 Рад на ову тему изложен је на петом научном скупу студената СТУдКОН 5 на Филозофском факултету у Нишу, а овде дајемо допуњену и проширену верзију. 
карактера и оставља доста простора не само за структурнограматичко поређење израза, већ и за когнитивнолингвистички, културолошки и историјски приступ њиховом испитивању. Стога је и циљ нашег рада вишеструк:

- настојимо ексцерпирати фразеолошке конструкције у албанском, грчком и српском са слатком компонентом, под којом подразумевамо све лексеме којима се денотира одређени десерт или зачин и пронаћи њихове преводне еквиваленте;

- утврдити контрастивно-компаративном методом сличности и разлике између анализираних фразеологизама, при чему се, ради што обухватнијег истраживања, не узима искључиво један језик као полазни;

- посебан акценат ће бити стављен на семантику фразеолошких јединица и испитивање у коликом обиму се оне групишу око позитивног, односно негативног концепта. Тиме би се утврдило посматрају ли балкански народи слаткише на истоветан начин и припадају ли они апсолутном балканском макрофразеолошком плану (Мутавџић 2016: 26) или фразеологизме са њима као кључном лексемом одликује већи степен идиотипичности.

Сви примери фразеологизама са слатком компонентом преузети су из општих и фразеолошких речника чији списак прилажемо на крају рада. Ради методолошке доследности, у раду ћемо напоредо користити појмове фразеологизам / фразеолошка јединища, према већ устаљеној терминологији Мршевић-Радовић (1987: 15). Поред тога, сви забележени изрази на албанском и грчком језику биће дати као глосе, у њиховом буквалном преводу, како би се лакше разумела позадинска слика фразеологизама. Како смо претходно истакли, сва три језика ћемо посматрати као полазне и циљне, при чему ће подударни преводни еквиваленти бити наглашени, а уколико се кључна лексема разликује, биће посебно подвучена. Такође, уколико у оквиру истог семантичког поља конфигурирају фразеологизми са слатком компонентом у сва три језика, навешћемо их у виду листе. У раду ћемо настојати да на одређеном броју примера 
прикажемо начин на који људи посматрају слаткише, оличен у фразеолошким конструкцијама, будући да би анализа свих израза превазилазила оквире нашег истраживања.

\section{2. Уводно разматрање о укусима}

Индивидуалност и субјективност сваког појединца најбоље описује изрека да о укусима не вреди расправљати

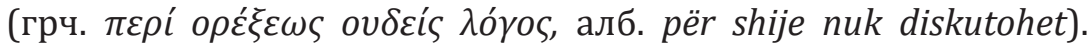
Пореклом из латинског de gustibus non est disputandum, остало је забележено, како наводе Валера и Русо, да ју је изговорио Цезар приликом посете Валерију Леонту у Милану. Том приликом су му послужене и шпаргле куване на путеру, што је за Римљане било веома одбојно, будући да су од масти користили искључиво уље (Валера и Русо 2018: 21). Ипак, иако је ова изрека непобитна, са̂мо питање (чула) укуса и расправе о њему заокупљало је пажњу филозофа и научника још од античких времена. Начинивши синоптички преглед историје истраживања о укусу, Барточек (1978) истиче да оно датира још од шестог века пре наше ере и старогрчког физичара Алкамеона који је веровао да језик као орган прима рецепторе кроз ситне поре. Свој допринос овом сложеном питању даље су давали и стари Грци и Римљани, попут Демоктира, Аристотела, Галена и других, али и научници током потоњих векова, да би своју ренесансу доживела током шездесетих година прошлог века када је амерички научник Стивенс открио нове психофизичке процесе (Барточек 1978: 4). Питање укуса и данас остаје отворено, имајући у виду да је, поред четири основна укуса, умами тек недавно званично признат као пети укус, упркос чињеници да га је пре више од века, тачније 1908. године открио јапански научник Кикунае Икеда (Ниномиа 2015: 1) који је и сковао назив умами, чиме се означава пријатан, пун, слан укус. 


\section{1. Перцепција слатког укуса}

Један од основних укуса чији се рецептори налазе при врху и са стране језика јесте слатко, а следствено томе и начин на који га свака особа доживљава релативно је универзалан, односно он је „биолошки заједнички свим живим бићима“ (Рафаели и Керовец 2017: 22). Незнатне разлике у начину на који посматрамо слатку храну, културолошки и лексички условљене, ипак се могу појавити између одређених народа, односно њиховог вокабулара. Тако Годард истиче да се за именовање слатког укуса у кантонском језику користи лексема tim, семантички проширена и на храну пријатног укуса и пиће уопште (Годард 2001: 43). Слично томе, у јапанском је у употреби термин amai, за који Бекхаус наводи да би се најбоље описао не само као слатки, већ и као благи укус (1994: 152). Без обзира на ова одступања од учесталог поимања слатког, може се рећи да су она занемарљива, будући да се и пријатни и благи укус, као и слатки, такође могу конципирати (веома) позитивно, па можемо говорити о универзалном схватању да је слатко пријатност. На основу тога, према теорији појмовне метафоре Лејкофа и Џонсона², Баљи постулира концепт ЗАДОВОљСТВО ЈЕ СЛАТКО (Баљи 2017: 33), док готово идентично наводи и Вајник путем метафоре ЗАДОВОљСТВО ЈЕ СЛАДАК УКУС (Вајник 2018: 141). Многобројна истраживања на тему концептуализације слатког у људској свести се поклапају у својим резултатима, истичући да се епитет слатко третира као пријатан укус и позитивна емоција, што се може објаснити чињеницом да људски организам од рођења поседује природне склоности ка слатком, па отуда и уживање у његовој конзумацији. Додатно, њиме се метафором и метонимијским

2 Суштина теорије појмовне метафоре представља доживљавање једног појма, односно ентитета путем другог (Лејкоф и Џонсон 1980: 5), при чему је битно истаћи да је један домен увек апстрактнији и могуће га је разумети преко другог, конкретног појма са којим је у непосредној вези (Кевечеш 2004: 4). 
трансфером ${ }^{3}$ може описати и привлачна особа, најчешће мислећи на женски пол (уп. Свитсер 1990: 28; Ковалчик 2019: 94; Забалотскаја 2017: 39-40; Андерсон 2014: 99; Пипер 2016: 167; Кевечеш, 2004: 26; Негро 2019: 51). Оваква слика се уочава уколико посматрамо дефиницију лексеме сладак (алб. ёmbël,

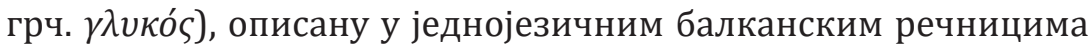
на следећи начин:

- који има укус меда, шећера, зрелог воћа и сл, заслађен; (о мирису) пријатан, угодан; фиг. који се радо доживљава, испуњен задовољством, радошћу, срећом, пријатан; који се радо слуша, пријатан, мио, симпатичан; мио драг, љубак, допадљив; који одаје, изражава симпатије, наклоност, уживање; са избледелим значењем у присном обраћању, мио, драг (РМС 2011: 1213);

- који има укус шећера или меда и генерално, који је укусан; фиг. који изазива пријатно осећање (РАA 2014: 377);

- који има укус шећера или меда, који има слаткоћу; који угађа слатким укусом; који угађа уху, носу или оку, који је пријатан да се чује, помирише или види; који доноси физичко и духовно задовољство; ко је љубазан према другима, драг, мио човек (РААН 1980: 441-442).

Како се може закључити из приложеног, уочава се слика да се у људској свести укус слатког готово искључиво везује за позитивна осећања и метафорички описује драге особе, као и друге врсте чула, попут слуха или мириса. Поред тога, примарна асоцијација на укус слатког јесу управо два основна заслађивача, редовно коришћена у исхрани трију балканских народа - мед и шећер.

Са друге стране, уколико се мало дубље погледа у семантику колокација и фраза са лексемом сладак, запажа се

3 Метонимијом се, према Лејкофу и Џонсону (1980: 35), један ентитет користи како би упутио на стварну особу, што треба разликовати од персонификације, путем које се људске особине приписују предметима и неживим стварима. 
нешто измењена представа. Наиме, постоје и одређени изрази негативне конотације, попут слатке речи и бити сладак на језику чиме се означава извештаченост и неискреност (Хрњак 2013: 195; Мацан и Вучајнк 2013: 225). Друкчије речено, такве слатке компоненте у језичкој употреби могу да „метафорично упућују на извештачену љупкост испод које се крије лични интерес" (Марчета 2016: 128), што је могуће објаснити и додавањем слатке компоненте на горак предмет, у овом случају речи, чиме оне постају „вештачки заслађене“. Занимљив пример дала је и Мендаш (2018: 36), истакавши да колокације попут слатке муке, слатке бриге, сладак терет носе у себи негативну конотацију која се може претворити у позитивну у тренутку када људи остваре свој циљ због којег су били забринути или у потешкоћи.

Из горе наведеног произилази да се у људској свести појам слатког укуса, изражен у језику метафорички или путем фразеологизама описује двојако, односно да га одликује бивалентност. Тако, са једне стране, слатко се генерализује као искључиво пријатан појам који доноси срећу и задовољство, припадајући ПОЗИТИВНОМ семантичком пољу. Насупрот томе, може се уочити и одређени број лексичких конструкција око којих се групише појам сладак НЕГАТИВНЕ семантике. У таквим изразима покушава се прикрити каква „горка“ ствар, односно сакрити њен првобитни, непријатан укус, због чега јој се додаје епитет сладак чиме би се исконски укус „замаскирао“. Оваква двојака слика изузетно је занимљива, будући да показује две крајности, због чега смо се и одлучили да управо балкански фразеологизми са слатким компонентама буду тема нашег рада.

\section{3. Слаткиши у фразеолошким конструкцијама}

Укупан број забележених фразеологизама ексцерпираних из речника јесте 113, од чега је највише у албанском (57), знатно мањи број на српском (35), док их је најмање у грчком језику, свега 27. Предуслов за сврставање у корпус нашег 
рада био је да фразеолошке јединице у свом саставу садрже слатку компоненту, која се може односити како на природне заслађиваче и зачине, тако и на десерте припремљене са њима. Како смо установили, фразеолошке јединице у албанском, грчком и српском образују се око различитих кулинарских лексема, а према бројности и сличности на првом месту је свакако мед (уп. Мутавџић и сарадници 2012: 456), а потом шећер. На основу прикупљене грађе, табеларни приказ слаткиша у балканској фразеологији представљен је Табелом 1. према азбучном редоследу.

Табела 1. Слаткиши у балканској фразеологији према азбучном редоследу

\begin{tabular}{|c|c|c|c|}
\hline $\begin{array}{c}\text { слатка } \\
\text { компонента }\end{array}$ & албански & грчки & српски \\
\hline алва & 4 & & 1 \\
\hline баклава & 2 & & \\
\hline бестиљ & 1 & & 1 \\
\hline бомбона & 4 & 5 & 9 \\
\hline кекс & & & \\
\hline колач & 6 & & 1 \\
\hline крем & & 1 & \\
\hline крофна & & 11 & \\
\hline мед & 19 & & \\
\hline обланда & & 1 & \\
\hline палуза & 2 & & \\
\hline ратлук & 4 & 1 & \\
\hline реванија & 1 & & \\
\hline слатко & & & \\
\hline торта & 1 & & \\
\hline уштипак & 3 & & \\
\hline шећер & 10 & & \\
\hline шлаг & & & \\
\hline
\end{tabular}


Отуда као главни заслађивач, све до доласка његовог главног „противника“, шећера, у Европу током крсташких ратова, мед је био основна слатка намирница српског, али и других балканских народа. О томе сведоче и разноврсни етнографски и митолошки записи, истичући његову двојаку улогу као хране богова и хране која се служила приликом одређених обреда, најчешће свадби (Николић 2012: 255). Мед је коришћен и за „справљање слаткиша и напитака, али и као додатак јелима“ (Зиројевић 2005: 250). Ипак, иако цењен подједнако међу припадницима хришћанске и исламске вере, начин његове употребе се разликовао. Мед се код Арапа првенствено користио као заслађивач у чајевима, а био је познат и по својим лековитим својствима, док су, са друге стране, хришћани поред ових благодети меда ферментацијом добијали и медовину (Абот 2009: 23). Данас се, као главна замена за мед користи првенствено шећер, који је временом заузео примат у слатком свету и чија је употреба далеко разноврснија. Као резултат тога, данас је „сама идеја слатког у европској мисли и језику постала повезана са шећером“ (Минц 2017: 49-50). Даље лексеме које улазе у фразеолошки фонд анализираних балканских језика у одређеној мери варирају, на шта могу утицати историјске околности ${ }^{4}$, обичаји као и култура исхране. Тако, на пример, у грчком језику сусрећемо

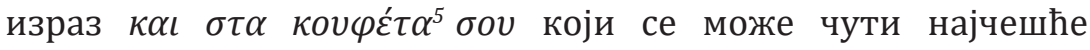
приликом свадбе, а служи за изражавање жеље одређеној особи да она буде следећа на реду за женидбу/удају. Такође, у српском фразеолошком фонду наилазимо на лексеме попут кекс и обланда, посластице са Запада које су на Србију имале већи утицај него што је то случај са Грчком и Албанијом, што

4 Треба назначити да то није увек случај, што можемо видети на примеру лексема ратлук или слатко, које не образују ниједан фразеологизам у српском језику. Ипак, то не умањује значај ових оријенталних посластица у српској кухињи, већ само показује да оне нису имале толико важно место, као на пример обланде које сусрећемо у изразу завијати нешто у обланду.

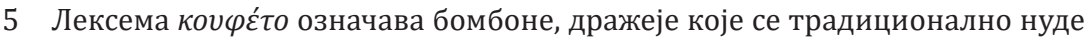
свим гостима у Грчкој приликом свадби или крштења, обично са укусом лешника, беле или розе боје, послужене у пакетићима са машницом. 
још једном доказује како је фразеологија „један од најважнијих извора за реконструкцију језичке слике света“ (МршевићРадовић 2014: V).

\section{4. Анализа фразеологизама}

Метафоричка употреба лексеме мед у значењу сладак може се уочити у застарелом фразеологизму библијског порекла мед му капље (тече) из уста, а којим се „у српској фразеологији илуструје 'добра' употреба језика када је реч о садржају говорења“" (Мршевић-Радовић 2014: 24). Исказујући слаткоречивост, пријатност, љубазност, овај израз има своје апсолутно подударне преводне еквиваленте у грчком и албанском:

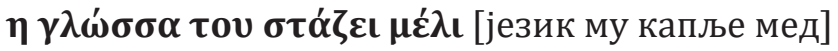
nxjerr mjaltë nga goja [извлачи мед из уста]

Њихова семантичка порука може се пренети и проширеним објекатским номиналним конструкцијама у српском и албанском са додатном намирницом, чиме се постиже интензивирање његовог слатког укуса:

\section{говорити мед и млеко}

бити мед и шећер

ка ngrënë bukë e mjaltë [појео је хлеб и мед]

Такође, комутација лексеме мед с неком другом слатком намирницом, једнако значајном за прехрамбене навике и обичаје тог народа, могућа је у неколико забележених случајева, и то само у албанском језику:

e ka gojën llokum / sheqer / mjaltë [има уста (као) ратлук / шећер / мед]

ka ngrënë mjaltë [појео је мед] është sheqer i gjallë [бити живи шећер]

ка ngrënë më shumë mjaltë se bukë

[појео је више меда него хлеба]

nxjerr sheqer nga goja [извлачи шећер из уста] 
Насупроттоме,претеранаслаткоћаможесеокарактерисати и као нешто негативно, што утиче на метафоричко осликавање ових фразеологизама као извештачене, неприродне љубазности, чиме би са̂ма употреба израза зависила од контекста и поруке коју говорник жели да искаже.

Синтагму мед и млеко уочавамо у оквиру израза којима се исказују пријатељски и(ли) љубавни, односно добри међуљудски односи:

e ka mjaltë e qumësht ${ }^{6}$ (me dikë)

[има мед и млеко (са неким)]

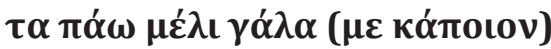

[ићи мед и млеко (са неким)]

бити мед и млеко (са неким)

а исти концепт се може изразити грчким фразеолошким јединицама са лексемама мед и шећер:

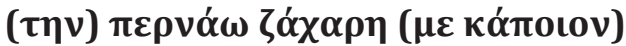

[проводити шећер (са неким)]

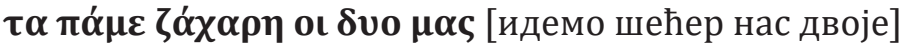

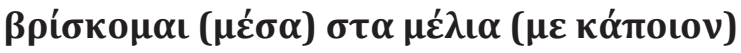

[налазим се у меду (са неким)]

У перцерпцији торте као предмета на спрат при чијем врху се налази одређени „додатак“ са функцијом истицања врхунца нечег лепог крије се позадинска слика која је мотивисала настанак фразеолошких јединица:

qershi mbi tortë [трешња на торти]

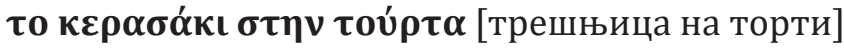

шлаг / трешњица на торти

Симболичко приказивање слатких намирница у позитивном контексту може се односити и на концепт благостања, повољне ситуације особе која се нашлау близини каквог слаткиша, што илуструју наредни фразеологизми:

6 Лексема млеко се у албанском може заменити компонентама шећер и путер што уочавамо у изразима e ka mjaltë e sheqer / e ka mjaltë e gjalpë. 
тече мед и млеко

упала је некоме секира у мед

вадити секиру из меда

набрати меда

масни колачи

ka njërën dorë në bakllava dhe tjetrën në revani / mjaltë [има једну руку на баклави, а другу на реванији ${ }^{7}$ / меду]

ka rënë në mjaltë [(у)пао је у мед]

i ra sëpata në mjaltë [упала му је секира у мед]

si veza në kulaç [као јаје у колачу]

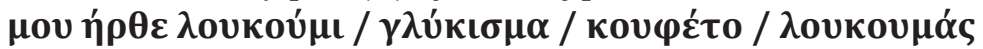

[дошао ми је ратлук / слатко / бомбона / крофна]

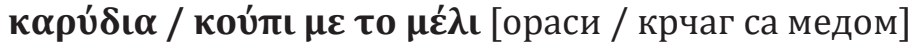

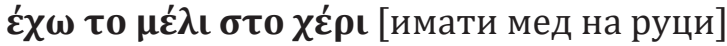

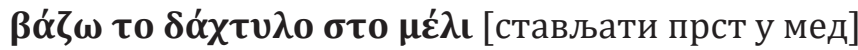

Најфреквентија слатка лексемау овим изразима јесте медчији су пријатан укус балкански народи посматрали готово истоветно и изједначавали га са срећом и успехом. То је, како истиче Шипка „сасвим логичан (избор) јер, у пренесеном смислу, означава сласт и задовољство“ (Шипка 2013: 266), те је на основу такве слике могуће постулирати појмовну метафору МЕД ЈЕ БЛАГОСТАҢЕ.

Како су већ многобројна истраживања доказала, људи показују склоности првенствено ка слатком укусу, дефинишући га као нешто пријатно, укусно, примамљиво. Привлачност коју осећамо можемо уочити и у фразеологизмима, где се човек метонимијским трансфером замењује животињама:

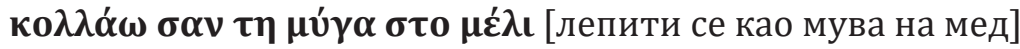
u lëshuan si miza në mjaltë [пустили су се као муве на мед] ићи као пчела на мед

који се, ипак, могу посматрати негативно и припадати домену непромишљености, брзоплетости када описују особу која без размишљања хрли на нешто што јој се касније може и обити о главу.

7 Реванија је врста колача преливена шербетом са лимуном. 
Негативна семантика фразеолошких јединица са слатком компонентом може се уочити код два српска и једног албанског фразеологизма, у којима се лексема колач изједначава са штетом, злом те је могуће постулирати појмовну метафору КОЛАЧ ЈЕ НЕСРЕЋА:

\section{спремити некоме колач}

i gatuan kulaçin (dikujt) [спремио је колач (некоме)]

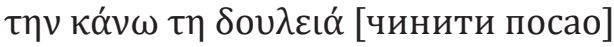

\section{увалити некоме црн колач у торбу}

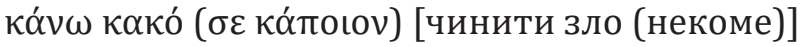

i hap telashe [отворити (некоме) проблеме]

У гастрономском погледу, додавање зачина је од кључног значаја како би се успоставио баланс укуса у јелу и задовољило људско непце, а једна од најтежих ствари представља ублажавање горког, непријатног укуса. При томе се обично додаје одређени заслађивач, а што је послужило као позадинска слика за настанак фразеологизама којима се исказује сакривање правог, лошег стања ствари или претварање:

e lyen me sheqer (diçka) [маже шећером (нешто)]

завијати у обланду

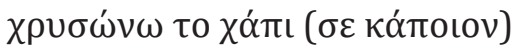

[позлаћивати пилулу (некоме)]

\section{преко једа мед просипати}

e ëmbëlsoi me sheqerka [засладио је бомбонама (нешто)]

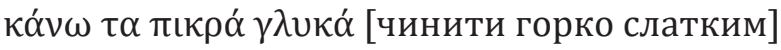

Фразеолошке јединице представљају језичне конструкције настале као производ људске маште чија је сврха што сликовитије описивање њима блиских и сродних предмета, појава, запажања и слично. Сходно томе, у састав израза улазиле су искључиво оне лексеме које су, према одређеној физичкој карактеристици, могле бити доведене у везу са позитивним и(ли) негативним концептом. Тако, на основу своје пихтијасте, желатинасте форме, у албанском сусрећемо изразе везане за концепт насиља: 
e bëri pelte / pestil (dikujt) [направио је (некога) палузом ${ }^{8}$ / бестиљом $\left.{ }^{9}\right]$

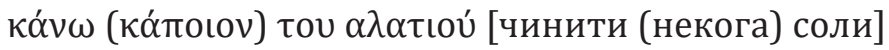

пребити (некога) као вола у купусу

Као једна од најзахтевнијих кулинарских области сматра се управо посластичарство, из разлога што су слатки рецепти далеко компликованији и захтевају прецизност у мерама, комбинацијама и састојцима, те би, уколико би се додала и(ли) изоставила једна компонента, десерт био неуспешан. Тако, за изражавање немогућности / тражење немогућег сусрећемо изразе:

\section{i bën petullat me ujë (pa vaj)}

[прави уштипке са водом (без уља)]

од тог брашна неће бити погача

коú

[шупљи ораси не чине питу]

\section{bën bakllava me miell thekre}

[прави баклаву са ражаним брашном]

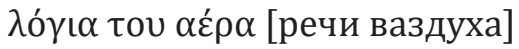

празне речи

bën kulaç në hi [прави колач у пепелу]

зидати куле у зраку

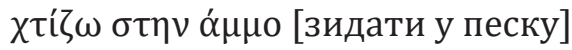

kërkon petulla me gjalpë [тражи уштипке са путером]

тражити и од птице млеко

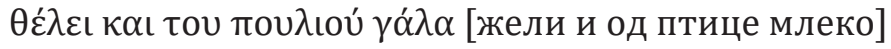

Наредни фактор који може утицати на мотивацију фразеолошких јединица са слатком компонентом јесте и њихова текстура, осећај који се ствара у људским устима. За бомбону, обично чврсте текстуре и која се не жваће већ сиса, потребно је више времена како би се растопила, па се отуда

8 Палуза је у албанској кухињи врста густог компота.

9 Бестиљ представља густо укувани пекмез од шљива. 
концепт понављања у грчком изражава фразеолошким јединицама:

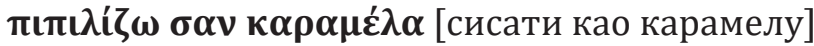

вртети увек исту плочу

i bie një avazi [удара једну причу]

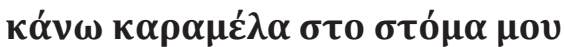

[чинити карамелу у мојим устима]

понављати једно те исто

bathë, bathë, po një kokërr [боб, боб, исто (су) једно зрно]

Људске прехрамбене навике, већ дубоко укорењене и устаљене, условиле су и „правила“ како се и на који начин једе одређено јело. Тако, семантичком пољу безнадежности / безначајности може се приписати и албанска номинална синтагма:

hallvë e ftohtë [хладна алва]

јака ствар

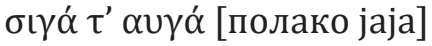

а колико смо у природи сладокусци и ипак не волимо превише да делимо храну на најбољи начин карактерише клетва „шаљивог“ карактера на албанском који се на грчки и српски може пренети само описно:

të ngrënsha hallvën [да ти поједем алву]

цркни

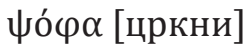

мада, колико год волели слаткише и десерте, треба напоменути да су они неретко представљали изузетак, а не правило у свакодневним оброцима, па се зато каже како:

nuk hanë çdo ditë llokume [не једу сваки дан ратлук]

није сваки дан Бадњи дан

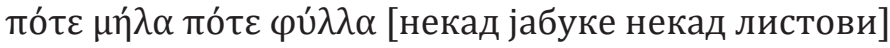

У култури исхране различитих народа одређена јела и намирнице заузимали су важније место у прехрамбеној 
хијерархији, те се концепт цењености и потражње може исказати фразеолошким конструкцијама:

\section{ићи као алва / щећер}

shihet si hallvë [иде као алва]

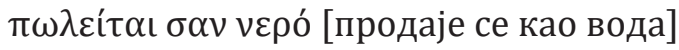

а неоспорно конципирање слатког као нечег позитивног и пријатног, што прија нашим чулима и буди у нама осећај среће и задовољства поткрепљује и уврежено схватање да се најслађе увек оставља за крај, фразеолошки исказано:

\section{шећер долази на крају}

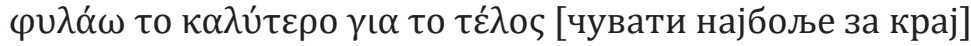

ruan më të mirën për fund [чува најбоље за крај]

Таквим редоследом, да се нешто слатко оставља за крај, одговара и типичан, устаљени оброк или гозба, на којем се десерт увек служи последњи, након свих сланих јела, чиме се метафорички „заокружује“. Другим речима, не постоји насумичан начин послуживања, већ тачно утврђена правила, комбинације и редослед, што Монтанари (2011: 121), правећи паралелу са језиком и граматиком, назива синтаксом јела.

\section{5. Закључак}

Описивање и изучавање чула укуса од давнина је заокупљало пажњу научника и филозофа, а оно и данас оставља доста простора за истраживање са најразличитијих аспеката. Када говоримо о узајамном односу чула укуса и лингвистике, пажња је првенствено усмерена ка семантици и испитивању у коликој мери долази до поклапања увреженог схватања слатког као нечег лепог и горког и киселог као одбојног базираног на емоцијама које у нама буде ти укуси и онога што се помоћу њих исказује у језику.У нашем раду смо се конкретно определили само за сладак укус, који смо посматрали кроз призму фразеологије три балканска народа. Као услов да у корпус уврстимо одређени израз било је неопходно да се у 
његовом саставу налази лексема којом се денотира или слатка намирница или десерт. На основу прикупљене грађе, утврђено је да превагу свакако односе мед и шећер, око којих се образује највећи број фразеолошких јединица у сва три језика. Са друге стране, одабир осталих лексема које су нашле своје место у фразеолошком фонду условљен је историјски и културолошки, али и гастрономским навикама Албанаца, Грка и Срба. Тако, једино се у грчком јавља лексема слатко, у српском обланда, а у албанском баклава, што ће рећи да су ови десерти (били) од већег значаја у њиховој култури исхране и да су зато нашли своје место у фразеологији. Ипак, ове слатке компоненте одраз су пређашњих прехрамбених навика, у великој мери потиснуте главним слаткишем модерног доба - чоколадом, коју не срећемо ни у једном балканском изразу ${ }^{10}$, што још једном доказује како су фразеолошке јединице носиоци традиције и културе, чији корени сежу далеко у прошлост.

Када говоримо о семантици ексцерпираних фразеологизама, циљ нам је био да испитамо образује ли се више позитивних или негативних концепата и шта је мотивисало њихово значење. На основу спроведене анализе над једним бројем фразеологизама може се закључити да су ова два семантичка поља релативно равномерно заступљена. Ипак, разлози којима се одређени израз сврстава у позитиван, односно негативан концепт је различит:

- како можемо видети, лексеме које конфигурирају у оквиру позитивних концепата сва три језика, попут благостања, љубазности, пријатељства јесу првенствено мед и шећер. Управо се код фразеолошких јединица са њима као кључном компонентом уочава и највећи степен подударности како на формално-структуралном, тако и на семантичком плану. Таква слика не чуди, будући да су као главни заслађивачи били веома

10 Ипак, треба истаћи да је у данас у свакодневном говору све учесталији израз топити се као чоколада (услед пријатности, милине, среће), чији преводни еквиваленти на албанском и грчком гласе shkrihem si çokollatë [топим се као чоколада] / $\boldsymbol{\lambda} \mathbf{\iota} \boldsymbol{\omega} \boldsymbol{v \omega} \boldsymbol{\sigma} \boldsymbol{\alpha} \boldsymbol{v} \boldsymbol{\sigma o \kappa \boldsymbol { \alpha }} \boldsymbol{\alpha} \boldsymbol{\alpha} \boldsymbol{\alpha}$ [топити се као чоколада] и који ће једног дана несумњиво наћи своје место у фразеологији. 
цењени код сва три балканска народа, а сладак, привлачан укус је управо био тај који је првенствено мотивисао изразе у оквиру позитивних концепата;

- са друге стране, приликом анализе запазили смо и немали број негативних семантичких поља, попут претварања, насиља, понављања или немогућности. Оно што је битно истаћи јесте да је, за разлику од позитивних концепата, као позадинска, фраземотворна слика, послужио не сладак укус, већ пре форма или рецепт неког десерта. Тако, на основу своје пихтијасте масе, компот и пекмез су послужили да искажемо насиље, претећи да ћемо од некога направити ту смесу или, уколико покушамо направити уштипке са неодговарајућим састојцима, нећемо у томе на крају успети.

У раду смо настојали да, на основу једног броја прикупљених фразеолошких јединица у албанском, грчком и српском са слатком компонентом прикажемо како ови народи посматрају слаткише и шта је мотивисало њихов настанак. Како можемо закључити, фразеолошке јединице са позитивном конотацијом заиста су, у највећој мери мотивисане пријатношћу слатког укуса. Насупрот томе, оне које носе негативну конотацију крију другачију позадинску слику, на коју су утицале ствари попут текстуре слаткиша и традиционалног начина прављења десерта. Тиме се, још једном, доказује људска креативност и машта када говоримо о описивању и исказивању најразличитијих концепата стварима из његовог непосредног окружења. 


\section{ЛИТЕРАТУРА}

\section{Извори}

Албанска Академија наука 1980: Akademia e Shkencave të Shqipërisë, Fjalor i gjuhës së sotme shqipe. Tiranë: Akademia e Shkencave të Shqipërisë, Instituti i Gjuhësisë dhe i Letërsisë.

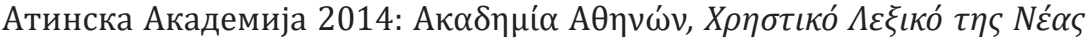

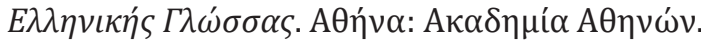

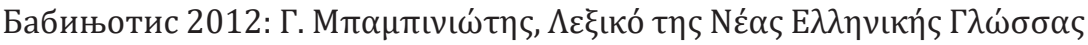

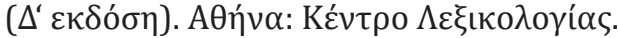

Влахопулос 2007: $\Sigma$. В $\lambda \alpha \chi о$ то

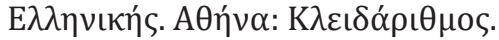

Головић 2010: Б. Головић, Фразеолошки српско-италијанскофранцуски речник. Београд: Албатрос плус.

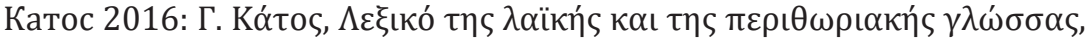

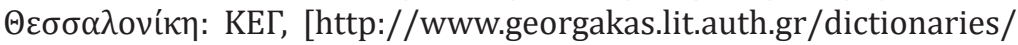
index.php/leksika/katou/g]

Ковачевић 2010: Ž. Kovačević, Frazeološki rečnik: srpsko-engleski. Beograd: Građevinska knjiga.

Матешић 1982: J. Matešić, Frazeološki rječnik hrvatskoga ili srpskoga jezika. Zagreb: Školska knjiga.

Матица српска 1995: Матица српска, Речник српскохрватског књижевног језика (1-6). Нови Сад: Матица Српска.

Матица српска 2011: Матица српска, Речник српскога језика. Нови Сад: Матица Српска.

Милосављевић 2008: Б. Милосављевић, Српско-француски речник идиома и изрека. Београд: Завод за уџбенике.

Мутавџић 2007: П. Мутавџић, Грчко-српски речник идиома. Београд: ИК Јасен.

Оташевић 2012: Ђ. Оташевић, Фразеолошки речник српског језика. Нови Сад: Прометеј.

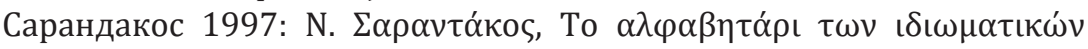
$\varepsilon \kappa \varphi \rho \alpha ́ \sigma \varepsilon \omega \nu . ~ A \theta \eta ́ v \alpha: ~ \Delta i ́ \alpha v \lambda о \varsigma$.

Српска академија наука и уметности 1958-: Српска академија наука и уметности, Речник српскохрватског књижевног и народног језика САНУ (том 1-19). Београд: Институт за српски језик САНУ.

Стефанлари 2000: I. Stefanllari, English-Albanian Dictionary of Idioms. New York: Hippocrene Books Inc. 
Стојановић и Балаћ 2009: М. Стојановић, А. Балаћ, Грчко-српски речник (2. издање). Београд: Завод за уџбенике.

Томаји 2010: J. Thomai, Fjalor frazeologjik i gjuhës shqipe. Tiranë: EDFA. Ћеску 1999: P. Qesku, Fjalor Shqip-Anglisht. Tiranë: EDFA.

\section{Референце}

Абот 2009: E. Abot, Statko-gorka istorija šećera. Beograd: Geopoetika.

Андерсон 2014: E. Anderson, Everyone eats: understanding food and culture. New York: New York University Press.

Баљи 2017: M. Bagli, Tastes we've lived by. Taste metaphors in English. Textus, English studies in Italy, 30(1), 33-48.

Барточек 1978: L. Bartoshuk, History of taste research. In: E. C. Carterette, M. P. Friedman (eds.), Handbook of Perception. Tasting and Smelling, New York: Academic, 3-18.

Бекхаус 1994: A. Backhouse, The lexical field of taste: A semantic study of Japanese taste terms. Cambridge: Cambridge University Press.

Вајник 2018: E. Vainik, Emotion meets taste: Taste-motivated emotion terms in Estonian. Folklore: Electronic Journal of Folklore, 71, 129154.

Валери и Русо 2018: L. Valera, M. Russo, Edo, ergo sum: Anthropological, ethical and educational considerations about eating. Persona $y$ Bioética, 22(1), 17-27.

Годард 2001: C. Goddard, Lexico-semantic universals: A critical overview. Linguistic Typology, 5, 1- 66.

Забалотскаја 2017: А. А. Забалотскаја, Фразеологизмы с прилагательными вкуса в английской и русской языковой картине мира. Необјављена докторска дисертација. Санкт Петербург: Филолошки факултет.

Зиројевић 2005: О. Зиројевић, Јело и пиће. У: Александар Фотић (ур.), Приватни живот у српским земљама у освит модерног доба, Београд: Clio, 233-258.

Кевечеш 2004: Z. Kövecses, Metaphor and emotion: Language, culture, and body in human feeling. Cambridge: Cambridge University Press.

Ковалчик 2019: A. Kowalczyk, Semantic transfers in the domain of FOODSTUFFS. Linguistics Beyond And Within, 5, 90-102.

Лејкоф и Џонсон 1980: G. Lakoff, M. Johnson, Metaphors we live by. Chicago/London: The University of Chicago Press. 
Марчета 2016: J. Марчета, Кулинарска терминолигија у француској, италијанској и српској фразеологији. Необјављена докторска дисертација. Нови Сад: Филозофски факултет.

Мацан и Вучајнк 2013: Ž. Macan, T. Vučajnk, Okusi v hrvaški, nemški in slovenski frazeologiji. U: M. Fabčić, S. Fiedler, J. Szerszunowicz (eds.), Phraseologie im interlingualen und interkulturellen Kontakt, Maribor: Univerza v Maribor, 223-237.

Мендаш 2018: S. Mendaš, A corpus-based contrastive analysis of selected English and Croatian lexemes for taste. Neobjavljen master rad. Rijeka: Filozofski fakultet.

Минц 2017: S. Minc, Slast i moć - mesto šećera u modernost istoriji. Novi Sad: Mediterran Publishing.

Монтанари 2011: M. Montanari, Hrana kao kultura. Zagreb: Sandorf.

Мршевић-Радовић 1987: Д. Мршевић-Радовић, Фразеолошке глаголско-именичке синтагме у савременом српскохрватском језику. Београд: Филолошки факултет.

Мршевић-Радовић 2014: Д. Мршевић-Радовић, Фразеологија и национална култура. Београд: Друштво за српски језик и књижевност Србије.

Мутавџић 2016: П. Мутавџић, Из балканске фразеологије. Београд: Филолошки факултет.

Мутавџић и сарадници 2012: П. Мутавџић, Д. Тодоровић, А. Сивачки, Кулинаризми у савременом српском, грчком и албанском језику. У: М. Ковачевић (ур.) Српски језик, књижевност, уметност, Крагујевац: Филолошко-уметнички факултет, 443-457.

Негро 2019: I. Negro, Metaphor and metonymy in food idioms. Languages, Formal and Methodological Approaches to Applied Linguistics, 4(3), 49-56. Николић 2012: В. Николић, Пчела (apis mellifica) као симбол у српској традицији (етнолингвистички аспекти). У: М. Ковачевић (ур.), Српски језик, књижевност, уметност, Крагујевац: Филолошкоуметнички факултет, 253-266.

Ниномиа 2015: K. Ninomiya, Science of Umami taste: Adaptation to gastronomic culture. Flavour, 4(13), 1-5.

Пипер 2016: D. Piper, Digitalni zalogaji: hrana kao spektakl na društvenim mrežama. AM Časopis za studije umetnosti i medija, 11, 163-170.

Рафаели и Керовец 2017: I. Raffaelli, B. Kerovec, The concept of 'taste' in formation of Croatian and Turkish lexicon: A contrastive analysis. Suvremena lingvistika, 43(83), 21-48.

Свитсер 1990: E. Sweetser, From etymology to pragmatics: Metaphorical and cultural aspects of semantic structure. Cambridge: Cambridge University Press. 
Хрњак 2013: A. Hrnjak, „Slatki život” frazeologije. U: H. Walter, V. M. Mokienko, D. Baláková (eds.), Die slawische Phraseologie und die Bibel, Greifswald: Ernst-Moritz-Arndt-Universität Greifswald, 195-198.

Шипка 2013: М. Шипка, Зашто се каже? (7. издање). Нови Сад: ИК Прометеј. 


\section{Sara Mandić}

\section{THE SWEET SIDE OF PHRASEOLOGY: AN ANALYSIS OF IDIOMS IN ALBANIAN, GREEK AND SERBIAN LANGUAGE}

\section{Summary}

The subject of our paper are idioms of three unrelated Balkan languages, Albanian, Greek and Serbian, that contain some of the key lexemes that nominate sweet ingredients or dessert. For the purpose of our paper, we shall refer to any such lexeme as the "sweet component". We analyse such idioms and their translation equivalents from a semantic point of view in order to determine the similarities and differences they show with the traditional conceptualization of sweet flavour as something very pleasant and satisfying. Based on our results, it is concluded that the phraseological units with sweet component belong both to the positive and negative semantic field. In terms of their motivation, the sweet taste plays an important role when it comes to the phraseological units with positive connotation, while, on the other hand, it does not affect idiom formation with negative meaning.

Key words: Balkan phraseology, idioms, Albanian language, Greek language, Serbian language, sweets. 